\title{
Copper-induced oxidative/nitrosative stress and excitoxicity in the neonatal period: neuroprotection with D-Penicillamine
}

\author{
Lajos Lakatos*, György Balla and István Pataki \\ University of Debrecen, Faculty of Medicine, Department of Pediatrics, Hungary
}

\begin{abstract}
This review focuses on the possible molecular mechanisms of the neonatal brain injuries: copper-induced oxidative/nitrosative stress and excitoxicity in the neonatal period. Firstly, it clears up the nature of these phenomenons in newborn babies. The emerging question: how to protect the neonatal brain? The authors' new concept addresses the medical necessity of chelation therapy (with D-Penicillamine - /D-PA/) in the neonatal period. The possible molecular mechanisms of D-PA in the neuroprotection [1]. It's a hybrid drug in the neonatal period by its ability to modulate both oxidative stress and nitric oxide (NO) pathway [2]. As a carbonyl scavenger, D-PA binds primarily to aldehydes in an irreversible manner; consequently this drug inhibits their damaging effects and scavenges peroxynitrite as well. So, it alleviates lipid peroxidation of the membranes in the neonatal brain [3]. Chelation therapy in neonates restores the normal activity of enzymes participating in heme metabolism. Briefly, chelating agents facilitate heme synthesis and inhibit heme degradation. In other words, this drug as a chelating agent, boost or inhibit the immature enzyme systems to the adult level [4]. Since reactive oxigen/nitrogen species (ROS/RNS) generation triggers glutamate-mediated excitotoxicity, D-PA can also be used as a copper chelator and strong ROS/RNS inhibitor against this dangerous phenomenon.
\end{abstract}

\begin{abstract}
Abbrevations: BG: Basal Ganglia, BBB: Blood-Brain-Barrier, BIND: Bilirubin-Induced Neurologic Dysfunction, BPD: Bronchopulmonary Dysplasia, CNS: Central Nervous System, D-PA: D-Penicillamine, NO: Nitric oxidei, NOS: Inducible Nitric Oxide Synthase, LP: Lipid Peroxidation, NHBI: Neonatal Hyperbilirubinemia, ND: Neurodegenerative Disease, NS: Nitrosative stress, OS: oxidative stress, ROP: Retinopathy of Prematurity, RBC: Red Blood Cells, ROS: Reactive oxygen species, RNS: Reactive nitrogen species, VEGF: Vascular Endothelial Growth Factor
\end{abstract}

\section{Introduction and aim}

The human brain is a unique organ with its biological complexity in the cranium. Although it adds up to only two-percent of total body mass, it consumes 20-percent of inhaled oxygen during respiration. Consequently, it needs high oxygen to control the accelerated oxidative metabolism. Moreover, the brain has among the highest levels of copper, as well as iron and zinc in the body [1]. These transition metals are essential micronutrients and play well-defined roles in cellular respiration, neurotransmitter production, pigment formation, peptide amidation, and in the connective tissue biosynthesis [2]. In our recently published review article [3] we have expounded that excessive metal (copper) accumulation in the nervous system may be toxic, inducing oxidative stress (OS), disrupting mitochondrial function, and impairing the activity of numerous enzymes. Damage caused by copper excess may result in permanent injuries, including severe neurological/ neurodegenerative disorders (NDs). The immature and strikingly vulnerable neurons play an important role in the pathogenesis of bilirubin-induced neurologic dysfunction (BIND) as well. The pathomechanisms of BIND have not been fully understood yet. Our concept addresses the medical necessity of chelation therapy (with D-Penicillamine - /D-PA/) in the neonatal period [4,5], as it is feasible that unconjugated bilirubin (UCB) molecule has particular affinity to copper stored in basal ganglia (BG) of the neonatal brain, where copperbilirubin complex can be formed [6]. Copper dyshomeostasis and OS have also been concerned in NDs such as Alzheimer, Amyotrophic lateral sclerosis or Menkes disease. These irreversible syndromes are related with a progressively aggravating lesions of neurons and injury of synaptic junctions in the central nervous system (CNS) [7]. This review focuses on the copper-induced oxidative/nitrosative stress (OS/NS) and excitoxicity in the neonatal period. First of all it is necessary to clear up the nature of these phenomenons especially in the the newborn babies.

\section{Possible molecular mechanisms of the neonatal brain injuries}

\section{Copper dyshomeostasis}

Both copper excess, and copper deficiency are jeopardous, creating mineral imbalances. Copper toxicity increases exponentially over generations. Recently, the number of those children are growing considerably who have neurotoxic conditions such as autism, schizophrenia, attention deficit disorder, dyslexia and learning disabilities which can be related to the accumulation and transmission of excess copper from one generation to the next [8,9]. In the neonatal period the human brain forms and develops over a long period, with

Correspondence to: Lajos Lakatos, Department of Pediatrics, Faculty of Medicine, University of Debrecen, 4032 Debrecen, Nagyerdei Krt. 1, Hungary, Tel: +36-52-225335, Fax: +36-52-225335, E-mail: lakatosl@kenezykorhaz.hu

Key words: copper toxicity, bilirubin-induced neurologic dysfunction, oxidative stress, copper-bilirubin complex, D-penicillamine in the neonatal period

Received: March 15, 2017; Accepted: April 22, 2017; Published: April 25, 2017 
neuron proliferation and migration. The blood-brain-barrier (BBB) does not work perfectly (immature) until the middle of the first year of life. The foetus exposured to toxic substances getting copper passively crosses the placenta with fetal levels of this metal often being higher than that of in the maternal blood. A recent report by the National Research Council found that $50 \%$ of all pregnancies in the US are now resulting in prenatal or postnatal mortality, significant birth defects, developmental neurological problems [10]. Moreover, the copper metabolism in Wilson's disease and in the newborn infants is strikingly similar: both have large quantities of copper in the liver (the fetal liver concentration is reported to be 16 times greater than that found in the adult [11]) and in the brain (mainly in the BG) which is contrasted by an unusually low ceruloplasmin level in the blood [12]. The copper almost equally capable to generate ROS and reactive nitrogen species (RNS) [13]. In addition, copper ions also activate several proangiogenic factors, for example: vascular endothelial growth factor (VEGF), basic fibroblast growth factor and interleukin-1, contributing to the development of retinopathy of prematurity (ROP) and bronchopulmonary dysplasia (BPD) in prematures [14].

\section{Oxidative stress}

In a biological context ROS have pivotal roles in cell signaling and homeostasis. However, under conditions of OS, ROS production is very high, resulting in damage of membranelipids, proteins, and nucleic acids that may become irreversible, even cause cell death. Oxidative damage occurs in the age-related diseases as well in a variety of pathological settings. It can also contribute to the aging process. The strategy which limits oxidant-induced tissue damage, called antioxidant defense mechanism, is a complex network of endogenous and exogenous systems for scavenging ROS. Binding of metal ions is also needed for up-regulation of exogenous/endogenous antioxidant defenses. The copper is the strongest redox-active metal which can generate excessive amounts of free radicals. Thus, we need such an antioxidants which have both metal-chelating and ROS/RNS-scavenging activity [5]. In the CNS a high rate of oxidative metabolism takes place. At the same time, the brain is more vulnerable to OS compared to other tissues. So, it seems reasonable that we need exogenous antioxidants which are effective in diminishing OS [15]. The BBB protects the neural tissue from harmful substances and toxins. It has the important function of maintaining brain homeostasis. Growing evidence suggests that ROS are key mediators of BBB breakdown and that they have been implicated in increased $\mathrm{BBB}$ permeability $[16,17]$. In the neonatal period excessive production of ROS and other highly reactive free radicals are capable of causing functional and structural damage to cell components. A series of conditions in neonates may, at least partly, be caused by oxygen radicals, e.g. periventricular leukomalacia, intraventricular hemorrhage, BPD, ROP, necrotising enterocolitis, patent ductus arteriosus and, may be, bilirubin encephalopathy (BIND) [18-22]. Free radicals are generated by exposure of newborn infants, particularlarly prematures, to high oxygen concentrations in resuscitation and mechanical ventilation. As mentioned above the presence of high concentrations of copper in their brain persuaded development of ROS most significantly in comparison with other metals [5]. In addition, newborn infants, especially preterm babies, are endowed with an immature antioxidant defense: lower levels of plasma vitamin E, beta-carotene, sulphydryl groups, plasma metal binding proteins such as ceruloplasmin and transferrin, as well as reduced activity of erythrocyte superoxide dismutase [23]. Consequently, they are proned to OS which may damage different organs (lung, brain, retina, and gastrointestinal tract), that will affect not only the survival but also the quality of life of these infants.

\section{Nitrosative stress (NS)}

Definition of this condition: „The reaction of body tissues to nitric oxide (NO), nitrous oxide or similar species' at levels greater than can be neutralized" [24]. It is a state resulting from exposure to excessive levels of NO or the highly redoxactive peroxynitrite produced following interaction of $\mathrm{NO}$ with superoxide anions. The NO plays a pivotal role in plants and mammals, including the human organism, as a negative or positive regulator of cell apoptosis. The cytotoxicity of NO has been studied in various tumour models, both in vitro and in vivo [25]. Thus, the RNSs are fundamental regulators of oxidative metabolism in the cell [26]. NO reacts rapidly with $\mathrm{O}_{2}$ and with superoxide radical $\left(\mathrm{O} 2^{-}\right)$ to generate a wide spectrum of RNSs that are highly damaging to cells $[27,28]$. Studies indicate that mitochondrial permeability transition and NS represent major factors in copper-induced toxicity in astrocytes, and RNSs can cause neuronal injuries [29]. In the neonatal period several studies attribute an important role for inducible nitric oxide synthase (iNOS)-induced NS in periventricular leukomalacia and in necrotizing enterocolitis [30-32].

\section{Lipid peroxidation (LP)}

LP occurs during the oxidative degradation of lipids. Initiation begins with ROS-induced hydrogen atom abstraction from polyunsaturated fatty acids (arachidonic-, linoleic-, eicosapentaenoicand docosahexaenoic acid). Two damaging products of LP are 4-hyroxynonenal and acrolein. Overproduction of ROS is creating a continuous cycle of ion imbalance, $\mathrm{Ca}^{2+}$ buffering impairment, mitochondrial dysfunction, glutamate-induced excitotoxicity and microvascular disruption. NO, formed from mitochondrial NOS, in turn reacts with superoxid anion to produce the highly toxic peroxynitrite radical [33].

In the neonatal period there are several conditions (hypoxia, hyperoxia, resuscitation, mechanical ventilation, phototherapy [34] and intracerebral hemorrhage [35] et cet), which set going the cascade of LP of unsaturated fatty acids leading to the formation of aldehydes as secondary LP products. These aldehydes can also act as messengers of ROS/RNS. Docosahexaenoic acid and arachidonic acid are important structural components of the CNS in the neonatal period. These fatty acids are transferred across the placenta, are present in human milk, and are accumulated in the brain during fetal and early postnatal period [36-39].

\section{Excitoxicity}

Excitotoxicity is the pathological process by which nervous cells are damaged and killed by the overactivations of receptors for the excitatory neurotransmitter glutamate, such as $N$-methyl-D-aspartate (NMDA)- and a-amino-3-hydroxy-5-methyl-4-isoxazolepropionic acid (AMPA) receptor [40]. These glutamate receptors and ion channel protein found in neurons. Excitotoxins like NMDA and kainic acid, as well as pathologically high levels of glutamate, can cause excitotoxicity by allowing high levels of calcium ions to enter the cell. This process activates a number of enzymes, including phospholipases, endonucleases, and proteases such as calpain. Latter enzymes go on to damage cell structures such as components of the cytoskeleton, membrane, and DNA. Excitotoxicity may be involved in stroke, traumatic brain injury and neurodegenerative diseases of the CNS such as multiple sclerosis, Alzheimer's disease, amyotrophic lateral sclerosis, fibromyalgia, Parkinson's- and Huntington's disease. In the neonatal 
period excitotoxicity is an important mechanism involved in perinatal brain injuries. Glutamate is the major excitatory neurotransmitter, and most neurons as well as many oligodendrocytes and astrocytes possess receptors for glutamate. Perinatal injuries caused by hypoxia-ischemia, stroke, hypoglycemia, kernicterus (or BIND), and trauma can disrupt synaptic function leading to accumulation of extracellular glutamate and excessive stimulation of these receptors $[41,42]$.

\section{How to protect the neonatal brain?}

Despite major improvements in perinatal care over the last decades, the incidence of disabilities due to perinatal injuries has not decreased significantly even in the developed countries $[43,44]$. It is difficult to find such an intervention or drugs that are able to neutralize separately or simultanously - the outlined noxious phenomenons [45]. Perinatal neuroprotection, however, is a major health care priority, and at the same time several questions remain actively debated particularly the problems of viability of the extremely small birth weight $(<500 \mathrm{~g})$ infants [46]. The feasibility of designing a strategy that prevents or treats brain damage without disrupting normal development will have to be evaluated. Therefore, there is a need to examine features which are potentially involved in multiple facets of neural insults $[47,48]$ including BIND, ROP and other neuropathological conditions. In this review we discussed above the role of elevated copper in various molecular mechanisms, focusing on the newborn infants. As a strong copper chelator D-PA may be a potential neuroprotector for acquired disabilities in the neonatal period.

\section{D-Penicillamine (D-PA): pharmacology and clinical uses}

D-PA ( $\beta$ - $\beta$-dimethylcysteine) was first isolated as the amine, from the degradation products of penicillin by Abraham et al. in 1942 [49]. It does not have any antibiotic activity and so initially, interesting the compound arose only out of its position in the processes of degradation and synthesis of penicillin. Nevertheless, it subsequently has found an extensive use in medicine: in 1956 by Walshe' in the treatment of Wilson disease [50]. It has since been used or suggested for use in the treatment of cystinuria, Rheumatoid arthritis (RA), juvenile RA, palindromic rheumatism, scleroderma, primary biliary cirrhosis, alcohol detoxification, heavy metal removal, chronic active hepatitis, morphea, keloid, keratosis follicularis, and hyperviscosity syndrome. In addition, as a ligand, it has to apply in the preparation of radiopharmaceuticals for liver and kidney imaging [51]. Only D-PA is used in medicine, since the $\mathrm{L}$ isomer and the $\mathrm{DL}$ isomer (or racemate), are toxic (Figure 1).

\section{D-Penicillamine in the neonatal period}

D-PA was first recognized as a potential benefit for neonatal hyperbilirubinemia (NHBI) [4]. During this time there was a remarkably low incidence of ROP in the infants treated with this drug [52-54]. Later, our studies were replicated in other institutes in

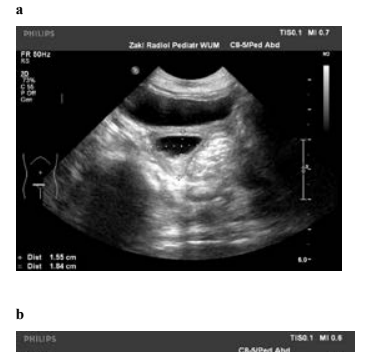

Figure 1. Structural formula of D-Penicillamine.
Hungary, Poland, the USA, India and Mexico [55-57]. It is important to note that there was no intolerance or short- or long-term toxicity of the medication, in spite of the fact that in the newborn period D-PA was used 10-20 times higher doses than those in adult. In our article [58] and in a recently published book [59] we discussed the potential neuroprotective effects of D-PA in BIND and ROP. D-PA is a hybrid drug in the neonatal period by its ability to modulate both oxidative stress and NO pathway. Tataranno et al. [60] have summarized the new body of knowledge about the antioxidant drugs for neonatal brain injury. D-PA-therapy of newborn infants may also have significant neuroprotective effects in cases jeopardized by BIND or ROP. (The retina, ie., despite its peripheral location, is actually part of CNS $[61,62])$.

\section{Possible molecular mechanisms of D-PA in the neuroprotection of neonatal brain}

The possible neuroprotective effects of D-PA emerged, when we did not observe any serious damage in the course of a long-term follow-up of adults (28-40 years old), who suffered from acut encephalopathy in their neonatal period [63].

\section{D-PA and the copper dyshomeostasis}

Chelation of high copper levels with D-PA, which used routinely for treating Wilson disease, also decreased brain-copper content of prion-infected mice by $30 \%$ and increased the incubation period, supporting the idea that increased levels of brain copper promote encephalopathies [64].D-PA is actually the drug most extensively used to treat copper overload $[65,66]$. Angiogenesis is a normal process in growth and development, as well as in wound healing. However, this is also a fundamental step in the transition of tumors from a dormant state to a malignant state, and in the development of various retinopathies. It is now recognized that the endothelial cells, by paracrine mechanisms, produces growth factors that stimulate the proliferation of blood vessels. The major targets of pharmacologic therapies are VEGF and basic fibroblast growth factor. Overall, angiogenesis can be viewed as the result of stimulatory and inhibitory peptides, proteases and endogenous inhibitors, and microenvironmental factors such as the level of oxygen or copper ion [67-69].

\section{DPA alleviates OS and NS}

These effects based on the capability of this drug to alter the NO system, and it is a strong antioxidant. Low molecular weight disulfides are the major products of D-PA metabolism in humans [70,71]. The oxidation of D-PA in vivo may also important in the mode of action of the drug through simultaneous reduction of the ROS and RNS. Consequently, D-PA fulfills the criteria of a hybrid drug in the neonatal period by its ability to modulate both oxidative stress and NO pathway, and can be a neuroprotective agent in the pathophysiology of neurologic dysfunction [72].

\section{DPA and lipid peroxidation (LP)}

Carbonyl scavengers [73] have been used with the aim of reducing the "aldehyde load" [74] and in several in vivo and in vitro studies have been investigated their effects on neuroprotection. The carbonyl scavenger D-PA binds primarily to aldehydes in an irreversible manner; consequently this drug inhibits their damaging effects and it also scavenges peroxynitrit. Acute D-PA administration has previously been shown to improve neurological recovery in the mouse concussive head injury model and to protect brain mitochondria [75]. 
Table 1. Age-related differences in the effects of D-Penicillamine.

\begin{tabular}{|l|c|c|}
\hline \multicolumn{1}{|c|}{ Hexobarbital } & Neonates & Adults \\
\hline sleeping time & & no effect \\
\hline Heme-oxygenase & shortened & no effect \\
\hline Cytochrom-P-450 & inhibited & no effect \\
\hline Catalase & increased & no effect \\
\hline Peroxidases & increased & no effect \\
\hline Radioprotection & increased & $?$ \\
\hline LD $_{50}$ & significant & $500 \mathrm{MG} / \mathrm{KG}(\mathrm{IV})$ \\
\hline
\end{tabular}

\section{Age-related effects of D-PA}

Paediatric patients display different pharmacokinetic and pharmacodynamic responses to drugs. This is why we can speak about developmental or age-related pharmacology [76]. In the Table 1 we demonstrate the results of our animal experiments regarding the agerelated differences in effects of D-PA [77]. The high activity of heme oxygenase $(\mathrm{HO})$ in the newborn could reflect the enzyme-inducing action of metals (primarily of $\mathrm{Cu}$ and $\mathrm{Fe}$ ) derived from the breakdown of fetal erythrocytes [78]. Chelation therapy in neonates restores the normal activity of enzymes participating in heme metabolism. Briefly, chelating agents facilitate heme synthesis and inhibit heme degradation. In other words, D-PA as a chelating agent, boost or inhibit the immature enzyme systems to the adult level. Because those enzymes that play an important role in antioxidant defense and drug metabolism (peroxidases, catalase, cytochrome P-450) are heme proteins, it can be assumed that in preventing hyperbilirubinemia and OS/NS, the mechanism of action of D-PA is identical: the protection of biomembrans against lipid peroxidation [79].

\section{D-PA and excitoxicity}

We did not find any article in the literature, accessible by us, that a direct inhibitory effects of D-PA on excitotoxicity would have been proved. However, it is well-known that the ROS generation triggers glutamate-mediated excitotoxicity. D-PA is used as a copper chelator and strong ROS/RNS inhibitor for the treatment of Wilson's disease and rheumatoid arthritis and it is known to scavenge carbonyls. Previous literature has shown penicillamine scavenging other toxic aldehyde by forming a thiazolidine compound with the aldehyde moiety $[33,80,81]$.

\section{Conclusion}

We hope that our concept will help answer some of the unsolved questions and concerns ocurred in the etiology and pathomechanisms of BIND and other neurodegenerative/neurodevelopmental disorders. The beneficial neuropharmacological actions of metal-targeted (chelating) agents most likely arise from local metal redistribution rather than from massive metal removal $[3,82,83]$. The chelation therapy for non-metal overload indications continues to be investigated. Our present article address the medical necessity of the use of a chelating agent (D-PA) in the prevention or treatment of neonatal brain injuries.

\section{References}

1. Yarris Y (2013) Copper on the brain. Neuroscience. [https://medicalxpress.com/ news/2013-05-copper-brain.html\#jCp]. Accessed May 27, 2013.

2. Wang Y, Zhu Sh, Hodgkinson V, Prohaska JR, Weisman GA, Gitlin J, et al. (2012) Maternofetal and neonatal copper requirements revealed by enterocyta-speci?c deletion of the Menkes disease protein. Am J Physiol Gastrointest Liver Physiol 303: G1236G1244. [Crossref]

3. Lakatos L, Balla G, Pataki I (2016) Bilirubin-Induced Neurologic Dysfunction: Neonatal Brain Insults of Metal (Copper) Dyshomeostasis. EC Paediatr 3: 281-288.
4. Lakatos L, Kövér B, Oroszlán G, Vekerdy Z (1976) D-penicillamine therapy in ABO hemolytic disease of the newborn infant. Eur J Pediatr 123: 133-137.[Crossref]

5. Balla G, Lakatos L, Vekerdy-Nagy Z (2015) Chelation therapy in the neonatal period D-Penicillamine can exert neuroprotective effects in kernicterus and retinopathy of prematurity. Internat J Pharmaceut Sci Res 6: 4269-4276.

6. Adhikari S, Joshi R, Gopinathan C (1998) Bilirubin as an anti precipitant against copper mediated denaturation of bovine serum albumin: formation of copper-bilirubin complex. Biochim Biophys Acta 1380: 109-114. [Crossref]

7. Ahuja A, Dev K, Tanwar RS, Selwal KK, Tyagi PK (2015) Copper mediated neurological disorder: visions into amyotrophic lateral sclerosis, Alzheimer and Menkes disease. J Trace Elem Med Biol 29: 11-23.[Crossref]

8. Casper J (2017) Copper Toxicity. Healthelite.org. ]http://nutritionalbalancing.org/ center/htma/science/articles/copper-toxicity.php]

9. Wilson L. (2016) Hair mineral analysis - an introduction. [http://www.drlwilson.com/ articles/HA\%20INTRO.htm]

10. Marlowe M, Cossairt A, Moon C, Errera J, MacNeel A, et al. (1985) Main and interaction effects of metallic toxins on classroom behavior. J Abnorm Child Psychol 13: 185-198. [Crossref]

11. Widdowson EM (1974) Trace elements in foetal and early postnatal development. Proc Nutr Soc 33: 275-284.[Crossref]

12. Chowrimootoo GF1, Scowcroft H, Seymour CA (1998) Caeruloplasmin isoforms in Wilson's disease in neonates. Arch Dis Child Fetal Neonatal Ed 79: F198-201. [Crossref]

13. Perrone S, Tataranno ML, Santacroce A (2014) The Oxidative Stress in the Fetus and in the Newborn. Perinatal and Prenatal Disorders Part of the series Oxidative Stress. In: Applied Basic Research and Clinical Practice: 395-411.

14. Rafi A, Ramakrishna D, Sabitha K (2011) Serum copper and vascular endothelia growth factor (VEGF) in dysfunctional uterine bleeding. Am J BiochemMolBiol 3: 284-290.

15. Dröge W (2002) Free radicals in the physiological control of cell function. Physio Rev 82: 47-95.[Crossref]

16. Pavlin M, RepiÄ M, Vianello R, Mavri J (2016) The Chemistry of Neurodegeneration Kinetic Data and Their Implications. MolNeurobiol 53: 3400-3415.[Crossref]

17. Pun PB, Lu J, Moochhala S (2009) Involvement of ROS in BBB dysfunction. Free Radic Res 43: 348-364.[Crossref]

18. Trindade CEP, Rugolo LM (2007) Free Radicals and Neonatal Diseases.NeoReview 8: e522-e532.

19. Escobar J, Cernada M, Vento M (2011) Oxygen and Oxidative Stress in the Neonata Period. Neo Reviews 12: e613-e624.

20. SaugstadOD (1990) Oxygen toxicity in the neonatal period. ActaPaediatrScand 79 881-892.[Crossref]

21. Sanderud J, Oroszlàn G, Bjøro K, Kumlin M, Saugstad OD (1995) D-penicillamine inhibits the action of reactive oxygen species in the pig pulmonary circulation. $J$ Perinat Med 23: 385-393.[Crossref]

22. OroszlánGy, Sanderud J, Saugstad OD, Lakatos L (1992) D-penicillamine: old drug, new indication? D-penicillamine reduced pulmonary hypertension induced by free radicals. Orv Hetil 133: 2835-2839.[Crossref]

23. Vento M (2011) Tailoring oxygen needs of extremely low birth weight infants in the delivery room. Neonatology 99: 342-348.[Crossref]

24. Wiktionary (2017) Definitions for nitrosative stress. [http://www.definitions.net/ definition/nitrosative $\% 20$ stress]

25. Hirst DG, Robson T (2010) Nitrosative stress as a mediator of apoptosis: implications for cancer therapy. Curr Pharm Des 16: 45-55.[Crossref]

26. Carreras MC, Poderoso JJ (2007) Mitochondrial nitric oxide in the signaling of cell integrated responses. Am J Physiol Cell Physiol 292: C1569-1580.[Crossref]

27. Pryor WA, Houk KN, Foote CS, Fukuto JM, Ignarro LJ, et al. (2006) Free radical biology and medicine: it's a gas, man! Am J Physiol Regul Integr Comp Physiol 291 R491-511.[Crossref]

28. Hirst DG, Robson T (2007) Nitrosative stress in cancer therapy. Front Biosci 12: 3406 3418.[Crossref]

29. Reddy PVB, Rao KVR, Norenberg M (2008) The mitochondrial permeability 
transition, and oxidative and nitrosative stress in the mechanism of copper toxicity in cultured neurons and astrocytes. Lab Invest 88: 816-30.[Crossref]

30. Haynes RL, Folkerth RD, Trachtenberg FL, Volpe JJ, Kinney HC (2009) Nitrosative stress and inducible nitric oxide synthase expression in periventricular leukomalacia. Actaneuropathol 118: 391-399.[Crossref]

31. De Vries LS, Connell JA, Dubowitz LM, Oozeer RC, Dubowitz V, et al. (1987) Neurological, electrophysiological and MRI abnormalities in infants with extensive cystic leukomalacia. Neuropediatrics 18: 61-66.[Crossref]

32. Zamora R, Bryan NS, Boyle P, Wong C, Milsom AB, et al. (2005) Nitrosative stress in an animal model of necrotizing enterocolitis. Free RadicBiol Med 39: 1428-1437. [Crossref]

33. Bains M, Hall ED (2012) Antioxidant therapies in traumatic brain and spinal cord injury. BiochimBiophysActa 1822: 675-684.[Crossref]

34. Sidrah, Priyanka T, Naaz A, Laksluni CG, Sridevi D (2015) Estimation of malondialdehyde and vitamin-E levels in neonatal hyperbilirubinemia before and after phototherapy. Int J Med Res Health Sci 4: 555-559.

35. Duan X, Wen Z, Shen H, Shen M, Chen G (2016) IntracerebralHemorrhage, Oxidative Stress, and Antioxidant Therapy. Oxid Med Cell Longev 2016: 1203285.[Crossref]

36. Innis SM (2003) Perinatal biochemistry and physiology of long-chain polyunsaturated fatty acids. J Pediatr 143 : S1-8.[Crossref]

37. Esterbauer H (1985) Lipid peroxidation products: formation, chemical properties and biological activities. In: Poli G, Cheeseman KH, Dianzani MU, Slater TF (eds). Free Radicals in Liver Injury. IRI Press, Oxford: 29-47.

38. Dianzani MU (1986) Biochemical effects of saturated and unsaturated aldehydes. In: McBrien DHC, Slater TF (eds). Free Radicals, Lipid Peroxidation and Cancer. Academic Press, London: 129-158.

39. Benedetti A, Comporti M (1987) Formation, reactions and toxicity of aldehydes produced in the course of lipid peroxidation in cellular membranes. BioelectrochemBioenerg 18: 187-202.

40. Excitotoxicity and cell damage. ScienceDaily.[https://www.sciencedaily.com/terms/ excitotoxicity.htm]

41. Ferriero DM (2004) Neonatal brain injury. N Engl J Med 351: 1985-1995.[Crossref]

42. Johnston MV (2005) Excitotoxicity in perinatal brain injury. Brain Pathol 15: 234-240. [Crossref]

43. Hagberg B, Hagberg G, Olow I, von Wendt L (1996) The changing panorama of cerebral palsy in Sweden. VII. Prevalence and origin in the birth year period 198790. Acta Paediatr 85: 954-960.[Crossref]

44. Vincer MJ, Allen AC, Joseph KS, Stinson DA, Scott H, et al. (2006) Increasing prevalence of cerebral palsy among very preterm infants: a population-based study. Pediatrics 118: e1621-1626.[Crossref]

45. Degos V, Loron G, Mantz J, Gressens P (2008) Neuroprotective strategies for the neonatal brain. Anesth Analg 106: 1670-1680.[Crossref]

46. Varga P, Gasparics A, Dombi Z, Jeager J, Rigó Jr. J, et al. (2017) Morbidity and mortality trends in very-very low birth weight premature infants in light of recent changes in obstetric care. Europ J Obst Gyn Repro Biol 211: 134-139.

47. Gressens P, Rogido M, Paindaveine B, Sola A (2002) The impact of neonatal intensiv care practices on the developing brain. J Pediatr 140: 646-653.[Crossref]

48. Johnston MV, Trescher WH, Ishida A, Nakajima W, Zipursky A (2001) The Developing Nervous System:A Series of Review Articles: Neurobiology of Hypoxic-Ischemic Injury in the Developing Brain. Pediatric Research 49: 735-741.

49. Abraham EP, Chain E, Baker W, Robinson R (1943) Penicillamine, a characteristic degradation product of penicillin. Nature 151: 107.

50. Howard-Lock HE, Lock CJ, Mewa A, Kean WF (1986) D-penicillamine: chemistry and clinical use in rheumatic disease. Semin Arthritis Rheum 15: 261-281.[Crossref]

51. Weigert WM, Offermanns H, Scherberich P (1975) D-Penicillamine--production and properties. Angew Chem Int Ed Engl 14: 330-336.[Crossref]

52. Lakatos L, Hatvani I, Oroszlán G, Balla G, Karmazsin L, et al. (1986) Controlled trial of D-penicillamine to prevent retinopathy of prematurity. ActaPaediatr Hung 27: 4756.[Crossref]

53. Lakatos L, Lakatos Z, Hatvani I, Oroszlan G (1987) Controlled trial of use of D-penicillamine to prevent retinopathy of prematurity in very low-birth-weight infants. In: Stern L, Oh W, Friis-Hansen B (eds). Physiologic Foundations of Perinatal Care.
New York: Elsevier 2: 9-23.

54. Phelps DL, Lakatos L, Watts JL (2001) D-Penicillamine for preventing retinopathy of prematurity in preterm infants. Cochrane Database Syst Rev: CD001073.[Crossref]

55. Rokicki W (1989) D-Penicylamina-nowylek w profilaktyce I terapiinoworodka? D-Penicillamine - A New Drug For Prevention And Treatment In Neonates. Polish Przeg Ped 19: 229-233.

56. Christensen RD, Alder SC, Richards SC, Lambert DK, Schmutz N, et al. (2007) D-Penicillamine administration and the incidence of retinopathy of prematurity. $J$ Perinatol 27: 103-111.[Crossref]

57. Tandon M, Dutta S, Dogra MR, Gupta A (2010) Oral D-penicillamine for the prevention of retinopathy of prematurity in very low birth weight infants: a randomized, placebocontrolled trial. Acta Paediatr 99: 1324-1328.[Crossref]

58. Lakatos L, Balla G (2015) Comment on "New Antioxidant Drugs for Neonatal Brain Injury”. Oxid Med Cell Longev 2015: 384372.[Crossref]

59. Lakatos L, Balla G (2016) D-Penicillamine in the neonatal period. Chelation as neuroprotectant in the neonatal period. LAMBERT Academic Publishing Editor: Gisca ISBN 978-3-659-86459-9.

60. Tataranno ML, Perrone S, Longini M, Buonocore G (2015) New antioxidant drugs for neonatal brain injury. Oxid Med Cell Longev 2015: 108251.[Crossref]

61. Lakatos L, Balla G (2015) Comment on "New Antioxidant Drugs for Neonatal Brain Injury”. Oxid Med Cell Longev 384372. [Crossref].

62. Purves D (2001) Neuroscience.( $2^{\text {nd }}$ edn). Sunderland (MA): Sinauer Associates; ISBN10: 0-87893-742-0.

63. Lakatos L, Balla G, Pataki I, Vekerdy Z (2015) D-Penicillamine in the Neonatal Period Case Reports. Internat J Med Pharmaceut 4: 59-63.

64. Tsukahara H, Kaneko K. (Eds.) (2014). Studies on Pediatric Disorders. Oxidative Stress in Applied Basic Research and Clinical Practice. ISBN 978-1-4939-0678-9.

65. Rupp H, Weser U (1976) Reactions of D-penicillamine with copper in Wilson's disease. BiochemBiophys Res Commun 72: 223-229.[Crossref]

66. Jullien AS, Gateau C, Lebrun C, Kieffer I, Testemale D, et al. (2014) D-Penicillaminetripodal derivatives as efficient copper(I) chelators. Inorg Chem 53: 5229-5239.[Crossref]

67. Chen J, Smith LE (2007) Retinopathy of prematurity. Angiogenesis 10: 133-140 [Crossref]

68. Leifeld L, Fielenbach M, Dumoulin FL, Speidel N, Sauerbruch T, et al. (2002) Inducible nitric oxide synthase (iNOS) and endothelial nitric oxide synthase (eNOS) expression in fulminan hepatic failure. J Hepatol 37: 613-9.[Crossref]

69. Pucci S, Mazzarelli P, Missiroli F, Regine F, Ricci F (2008) Neuroprotection: VEGF, IL-6, and clusterin: the dark side of the moon. Prog Brain Res 173: 555-573.[Crossref]

70. Joyce DA, Day RO (1990) D-penicillamine and D-penicillamine-protein disulphide in plasma and synovial fluid of patients with rheumatoid arthritis. Br J Clin Pharmacol 30 : 511-517.[Crossref]

71. Rahimi N, Sadeghzadeh M, Javadi-Paydar M, Heidary MR, Jazaeri F, et al. (2014) Effects of D-penicillamine on pentylenetetrazole-induced seizures in mice: Involvement of nitric oxide/NMD pathways. Epilepsy \& Behav 39: 42-47.[Crossref]

72. Arent AM, DeSouza LF, Walz R (2014) Perspectives on Molecular Biomarkers of Oxidative Stress and Antioxidant Strategies in Traumatic Brain Injury. Biomed Res Int. http://dx.doi.org/10.1155/2014/723060.

73. Aldini G, Dalle-Donne I, Facino RM, Milzani A, Carini M (2007) Intervention strategies to inhibit protein carbonylation by lipoxidation-derived reactive carbonyls. Med Res Rev 27: 817-868.[Crossref]

74. Wood PL, Khan MA, Kulow SR, Mahmood SA, Moskal JR (2006) Neurotoxicity of reactive aldehydes: the concept of "aldehyde load" as demonstrated by neuroprotection with hydroxylamines. Brain Res 1095: 190-199.[Crossref]

75. Singh IN, Sullivan PG, Hall ED (2007) Peroxynitrite-mediated oxidative damage to brain mitochondria: protective effects of peroxynitrite scavengers. J Neurosci Res85: 2216-2223.[Crossref]

76. Kearns GL, Abdel-Rahman SM, Alander SW, Blowey DL, Leeder JS, et al. (2003) Developmental pharmacology--drug disposition, action, and therapy in infants and children. $N$ Engl J Med 349: 1157-1167.[Crossref]

77. Lakatos L, Oroszlán G, Dézsi Z, Hatvani I, Karmazsin L (1982) Age-related difference in radioprotective effect of D-penicillamine. DevPharmacolTher 5: 120-126.[Crossref] 
78. Maines MD, Kappas A (1977) Metals as regulators of heme metabolism. Science 198: 1215-1221.[Crossref]

79. Lakatos L, Oroszlán G (1994) Possible effect of D-penicillamine on the physiologic action of inhaled nitric oxide in neonates. J Pediatr 124: 656-657.[Crossref]

80. MacAllister S, Martin-Brisac N, Lau V, Yang K, O’Brien PJ (2013) Acrolein and chloroacetaldehyde: An examination of the cell and cell-free biomarkers of toxicity. Chem-Biol Interact 202: 259-266. [Crossref]
81. Wondrak GT, Cervantes-Laurean D, Roberts MJ, Qrasem JG, Kim M, et al. (2002) Identification of alpha-dicarbonyl scavengers for cellular protection against carbonyl stress. Biochem Pharmacol 63: 361-373.[Crossref]

82. Mot AI, Wedd AG, Sinclair L, Brown DR, Collins SJ, et al. (2011) Metal attenuating therapies in neurodegenerative disease. Expert Rev Neurother 11: 1717-1745.[Crossref]

83. Jellinger KA (2013) The relevance of metals in the pathophysiology of neurodegeneration, pathological considerations. Int Rev Neurobiol 110: 1-47.[Crossref]

Copyright: $\odot 2017$ Lakatos L. This is an open-access article distributed under the terms of the Creative Commons Attribution License, which permits unrestricted use, distribution, and reproduction in any medium, provided the original author and source are credited. 